\title{
Debating a Minimum Marriageable Age for Girl in Indonesian Marriage:
}

\author{
A Semiotic Study
}

\author{
Nurina Azyyati \\ Universitas Indonesia \\ Depok, Indonesia \\ nurin.naa@gmail.com
}

\begin{abstract}
Issue of child marriage in Indonesia has always been a debate particularly since the rejection of a recent judicial review of the 1974 Marriage Law to raise a minimum marriageable age for girls by Constitutional Court. The judicial review was instigated by the association of women's and youth organizations, Koalisi 18+. The rejection sparks off a debate, especially since a research conducted by UNICEF (2016) had been published, stating that Indonesia ranked seventh with the highest absolute numbers of child marriage. Issues raised by UNICEF are in line with what Koalisi 18+ has voiced. On one side, in addition to violating the Human Rights, child marriage can also bring a harmful loss such as a low rates of health and life expectancy for women and children. It even creates an intergenerational poverty (in Grijns \& Horii, 2018). Yet, on the other side, Constitutional Court rejected it with considerations such as religious norms, social norms, as well as customs and traditions. Those debates then are analyzed through a semiotic analysis, a semiosis process by Danesi \& Perron (1999). From the analysis, it can be seen that the debates basically originate from the difference between Koalisi 18+ and Constitutional Court in interpreting marriage and its minimum marriageable age. It concludes that marriage in Indonesia is complex and its complexity involve many aspects under a culture sphere such as legal aspect, religiosity, and social norms.
\end{abstract}

Keywords—child marriage; minimum marriageable age; semiosis process; semiotic study

\section{INTRODUCTION}

Issue of child marriage in Indonesia has contributed to debate between party who agrees to raise a minimum marriageable age and those who reject it. The minimum marriageable age is a minimum age for girls to get married. It is getting crucial since UNICEF (2016) published their research which stated that Indonesia ranked seventh among the top ten global with the highest number of child marriage. On one hand, as stated by eight Constitutional Judges (cited from Ecpat, 2015), raising a minimum marriageable age is not an urgent issue and no need to fulfill that with reasons of religious norms, social norms, or customs and traditions which are explained later on analysis. On the other hand, Koalisi 18+ which instigates the petition, believes the urgency of raising a minimum marriageable age for it will cause a harm for both individual and society such as causing an intergenerational poverty (Kartika, 2016, in Grijns \& Horii, 2018). That is how raising a minimum marriageable age starts getting crucial because of its damages by causing low health rates for children and women, and the growth of poverty rates in
Indonesia. Yet other believe that the religious norms, social norms, as well as customs and traditions cannot also be neglected.

Along with those debates, there is the 1974 Marriage Law which covers and becomes a source of those debates regarding a minimum marriageable age for woman. The Marriage Law states in Article 7(2) that a minimum marriageable age, which is 16 for girl and 19 for boy written in Article 7(1), can be reduced by a dispensation from court. By that, basically there is no minimum age to get married for citizens in Indonesia.

Then, as those debates will be analyzed through semiotic study, the 1974 Marriage Law will be presumed as a signifying order. The signifying order which covers and becomes a source from those debates is reviewed through semiotic study by looking at its interpretation along with the contexts of debates as a sign and code. Then, the sign and code can produce interpretation for what occurs in the body, mind, and culture. For further explanation, code is a structural system in a paradigmatic, syntagmatic, or analogic format (Danesi \& Perron, 1999, p. 92) or to be precise is an area to cover signs which creates a structural system such as language code consisted of phonology sub-code, morphology sub-code, and others. In this research, interpreting debates as a sign and code is used as a research method to show how Constitutional Court and Koalisi 18+ makes their own interpretation of marriage and its minimum marriageable age for girls. Thus, this research aims to answer these questions through semiotic analysis by Danesi and Perron (1999) and semiotic study as follows: (1) how does a pro and contra party make their own interpretation about marriage and its minimum marriageable age for girls? (2) How does the interpretation define the concept of marriage and its minimum age in Indonesia?

\section{METHOD}

This research analyzes debates between Constitutional Court and Koalisi 18+ regarding a raise of minimum marriageable age in Indonesia for girls. The data of arguments from both Constitutional Court and Koalisi 18+ are gathered from Ecpat (2015). After denoting sign and code within those arguments under the 1974 Marriage Law as a signifying order, it is then analyzed based on a semiosis process by Danesi \& Perron which consists of firstness, secondness, and thirdness. Those three semiosis stages can be in any forms depends on its suitability. Afterwards, the analysis draws a conclusion of how 
a pro and contra party have their own interpretations of marriage and its minimum age for girls.

\section{RESUlt AND DISCUSSION}

\section{A. Legal Sphere}

It should be begun by explaining legal sphere at first. According to Danesi \& Perron (1999, p. 29), signifying order as macro-code which accommodates signs and codes, exist or manifest in an institution structure called "sphere". One of the biggest spheres is a culture sphere which "domesticates" so that humans are living with rules, not with instinct anymore. The culture sphere consists of other spheres; primary sphere and secondary sphere. The classification is based on its character; the primary sphere is stable and unlikely to change, meanwhile the secondary sphere is created by human's initiation and communal. Therefore the secondary sphere will change to the more appropriate one if the implementation is not satisfying enough. Then, according to those definitions, the legal sphere is within secondary sphere because of its communal character and its implementation are changeable if not fulfilling enough.

At first, this legal sphere is created by secular community who desires a regulation which are not always intended to "look above (like religious sphere)" but also to look at their surroundings. Thus, the legal sphere is created to substitute religious sphere (Danesi \& Perron, 1999, pp. 34-35). Also, the 1974 Marriage Law which is classified as a signifying order in this research is also manifested in legal sphere.

Cited from Grijns \& Horri (2018, p. 4-5) to looking back to 1973 when the Marriage Law was drafted, the government was about to enhance woman's right in marriage so that the minimum age which at first was intended to, was 18 year for girls. Yet, the Islamic party (Partai Persatuan Pembangunan) and conservative Muslim organization objected it. In the end, it was decided that the minimum age for girl to get married is 16 year old. Then, referring to the explanation above about legal sphere, it can be seen that legal sphere in Indonesia is not fully separated from religious sphere, and even control the legal sphere itself. Besides, the legal sphere as communal and changeable sphere is also seen from what Koalisi 18+ does; to change the current Marriage Law regarding a minimum marriageable age for girl. The aforementioned explanation about legal sphere in Indonesia is taken as a key to analyze signs and codes within the signifying order later.

\section{B. Semiosis process of marriage concept and its minimum marriageable age in indonesia}

Cited from Ecpat (2015), it is said that Constitutional Court does not recognize a minimum marriageable age in order to prevent pre-marital sexual relations which is supposed to be channeled through a legal marriage as well as religious approval. From that statement, the disapproval of judges of Constitutional Court to raise a minimum marriageable age is caused by a concern to prevent pre-marital sexual relations. Not only that, but the judges also brought up social norms and cultural issues to their disapproval which are explained later. It then opposed by Koalisi $18+$ which considers a harmful risk such as creating an intergenerational poverty and a possibility of a low health risks for both young mother and children. Koalisi $18+$ believes that marriage is more than just to "prevent zinah". Then, this paper analyze those statements by correlating it with a concept of marriage as an object of culture as well as an object of debates through semiosis process by Peirce which was later developed by Danesi \& Perron (1999). Here is the explanation below.

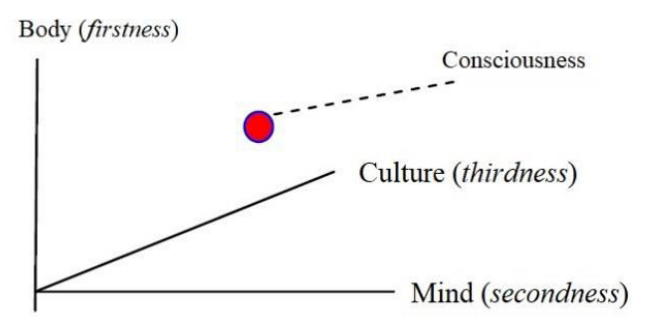

Picture 1. Interconnectedness Diagram between body, mind, and culture (Danesi \& Perron, 1999)

Through those three stages of Danesi \& Perron semiosis process, firstness is what is interpreted by body or a denotative meaning referring to Barthes' concept. From the firstness, the minimum marriageable age for girls is unrestricted or it depends freely to the subject as mentioned by signifying order, the 1974 Marriage Law, which allows dispensation (written in Articles 7(1) and 7(2)) to reduce a minimum marriageable age; 16 for girl and 19 for boy. It is even simplified by Constitutional Court by allowing village bureaucrats to give dispensation as well. Thus, if concept of marriage in Indonesia is seen from the firstness, marriage is a law-and-religion-based tie, precisely like Great Indonesian Dictionary (2016) said, to prevent a pre-marital sexual relation and children born out of wedlock. That concept becomes communal since marriage is within legal sphere which is a communal principle for all of the citizens where the law applies. Though at some points a legal sphere also blends with religious sphere. Also, since the concept of marriage is like that, the minimum marriageable age cannot be determined precisely in order to prevent child born out of wedlock or extra-marriage sexual relations.

Then, the firstness is going through semiosis process to the secondness. The secondness is a process of interpreting occurring in mind or connotative meaning referring to Barthes' concept of myths. The secondness is also a form of reflection of the firstness (Danesi \& Perron, 1999, p. 292). On the above-mentioned Constitutional Court argument, the concept of marriage and a minimum marriageable age can be seen from the firstness; a legal-and-religious-based bound to prevent pre-marital sexual relations and to prevent child born out of wedlock so that there is no limit to set a minimum marriageable age. It then leads to the secondness that, from the argument before, Constitutional Court does not consider any other risks that poses a child-bride if they are getting married under 18. Besides violating Human Rights, child marriage can also poses harm for girl such as a low health rate and creating intergenerational poverty (Grijns \& Horii, 2018). Moreover, (also in Grijns \& Horii, 2018), a court and even village 
bureaucracy $^{1}$ easily give a dispensation to reduce a standard marriageable age by their decision referring to the phrase "preventing zinah (the sin of pre-marital sexual relations)". Therefore, the secondness leads to the another concept of marriage and argument from Constitutional Court which looks like ignoring other harmful risks stated by UNICEF (2016) and Koalisi $18+$ such as risk on education, poverty, welfare, and health rates.

At the end, those two previous stages of the interpretation of marriage concept and its minimum age lead to the final stage, the thirdness, which is a cultural interpretation. Looking back at the firstness and secondness, Constitutional Court at the secondness appears like ignoring any other harmful risks for both individual and society which comes from the firstness, a concept of marriage and its minimum age which is argued by Constitutional Court. Then, as it has explained, a concept of marriage in Indonesia is driven by various factors such as religious factor like preventing zinah. However, the dispensation which is regarded easy to obtain and opposed by Koalisi $18+$ also derives from social norms, as well as customs and traditions.

To explain it further, this paragraph will enclose an example of social norm in Sukabumi as a condition for people to be able to get married. The condition is "kuat gawe" or being able to work which is intended for boys. Thus, as long as the boys are already be able to work and get money, they are allowed to get married even though they may be underage. It also comes to customs and traditions in Nias, a "lompat batu", to mark the maturity or adulthood of boy. For girl, in most of cultures, as long as the girls have already come to their periods, they will be regarded as mature and adult enough to get married. Thus, marriage and its minimum age in Indonesia involve many aspects and diverse from one area to another area. For further details, it can be seen from the map below.

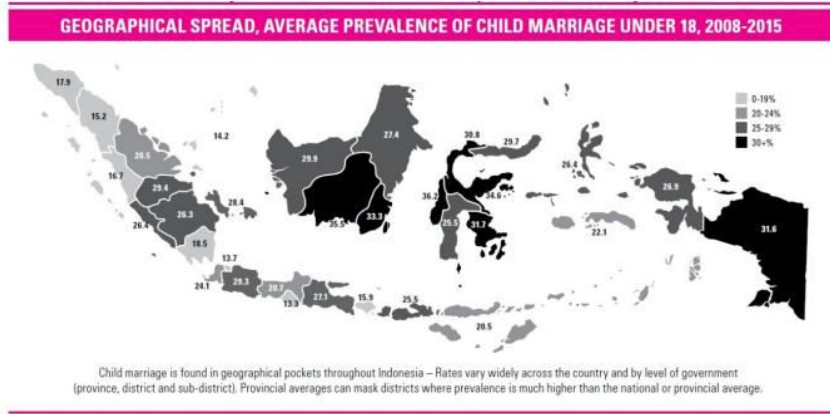

Picture 2 - Geographic Distribution Map of Child Marriage under 18year-old in Indonesia (UNICEF, 2016)

From the picture above, it displays that the concept of marriage in Indonesia is not always interpreted only from religious or legal sphere. For example, in Papua with the highest number of child marriage may not understand the phrase of "preventing zinah" since people in Papua have their own standard of maturity and adulthood in getting married.

\footnotetext{
${ }^{1}$ Village bureaucracy is allowed to give dispensation to reduce a minimum marriageable age if a court is hardly accessed by the villagers.
}

That constructs a cultural understanding that a marriage interpretation in Indonesia may vary since many aspects are involved, for instance religious norms, social norms, customs and traditions, and others. Thus, the debate of minimum marriageable age in Indonesia which is supposedly within legal sphere, as it is seen from the 1974 Marriage Law as a signifying order, is interpreted differently by each local communities though Islam rules may be still going strong until now. Then the analysis is continued to macro analysis of schematic and proxemics.

\section{Schematic Analysis}

In a schematic analysis, the firstness comes in an up-anddown form. To correlate it with the debates regarding a minimum marriageable age, the debates take place in a court. A court landscape also has its own meaning regarding a position. In a court, a judge sits in a higher position than applicant. In this case, the applicant is Koalisi 18+. Besides, a judge who sits in a higher position is called "Your Highness". It signifies that the judge has a higher position in a court.

Then, it leads to the secondness that since a judge has a higher position in a court, they also have a higher position in society since judge is within a legal sphere which is intended for communality. That means their decision leads to what it is believed as the best decision to the community. Thus, since judge has the higher position than other citizens and since the judges' decision will apply to the community, it represents of what is believed as the best for community.

Lastly, the thirdness is the accumulation of those two previous stages. It shows that Constitutional Court's decision regarding marriage and its minimum age which involves factors such as religious norms, social norms, as well as traditions and customs, also presents that those factors are regarded more important and is valued more than other factors such as health factor and economic factor. Thus, marriage in Indonesia is considered to be more about those religious, social, and tradition norms rather than health and economic factors.

\section{Proxemics Analysis}

Proxemics analysis is analysis based on the position of an object, whether it is positioned within a public space, private space, or sacred space. In this debate, the debate is basically a blend of those three spaces. It means that the debate of marriage and its minimum marriageable age is a complex question since it involves those three aspects at once. The explanation can be seen as follows.

Through proxemics analysis, a legal regulation and law is placed within a legal sphere. A legal sphere is a communal sphere, thus in proxemics, it becomes a public space. That is how a marriage which is also registered in law is also considered within a public space. Then, when it comes to public space, marriage is not only a matter between a bride and a groom, but also a matter for a community and even a country.

However, although marriage is within a public space, the decision of marriage is basically a subject's private decision. Whether the girl wants to marry or not, is a girl's business at 
first. Nevertheless, the problem comes to an arranged marriage when a girl does not want to marry yet, but their parents force them to. That is a cause of the concern of Koalisi 18+ about raising a minimum marriageable age. Therefore, a marriage is within a private place at first before it turns to be within a public space.

Meanwhile, a sacred space is also involved when the judges of Constitutional Court stating phrases like "preventing zinah". Besides, as it has been explained before, marriage in Indonesia also involves religious norms as well as customs and traditions which are deemed as "sacred". Therefore, it can be seen that a complexity of marriage in Indonesia also comes from the involvement of those three spaces.

\section{Acknowledgment}

A special thank you to Bapak Lilie Suratminto and Bapak FX. Rahyono, lecturers in Universitas Indonesia, for giving a broad knowledge of culture, especially Indonesian culture, during my study in Semiotics class. People are truly homo significans, always search for a true meaning within their own interpretations.

\section{References}

Danesi, M., \& Perron, P. (1999). Analyzing cultures: An introduction and handbook. Bloomington, Indianapolis: Indiana University Press.

Ecpat Indonesia. (2015). Pernyataan sikap koalisi 18+ atas Keputusan MK (Statement of Koalisi 18+ on the decision of Constitutional Court). Retrieved from http://www.ypha.or.id/web/?p=1608 pada 13 May 2018.

Grijns, M., \& Horii, H. (2018). Child marriage in a village in west java (indonesia): compromises between legal obligations and religious concerns. Asian Journal of Law and Society (pp. 1-14). Cambridge: Cambridge University Press.

Nikah. (n.d.). In Kamus Besar Bahasa Indonesia (the Great Dictionary of the Indonesian Language) online. Retrieved from: https://kbbi.kemdikbud.go.id/entri/nikah

UNICEF Indonesia. (2016). Child marriage in Indonesia: progress on pause: research brief. Jakarta: UNICEF Indonesia. 